\title{
USING DATE PALM SUCKERS AS MATERIAL FOR VEGETATIVE PROPAGATION BY GROWTH REGULATORS INJECTION
}

(Received: 15.12.2009)

\author{
By \\ E. I. Bakr, G. M. M. Haseeb, S. E. EL-Kosary and M. A. M. Bakir \\ Department of Pomology, Faculty of Agriculture, Cairo University, Giza, Egypt. \\ Horticulture Research Institute, Agricultural Research Center, Giza, Egypt.
}

\begin{abstract}
Date palm (Phoenix dactylifera L.) trees are essential components of farming systems in dry and semi arid regions and can be produced equally well in small farm units or in large scale commercial plantation units. Palm tree is an excellent candidate for cultivation in Egyptian agricultural projects in new reclamation regions, such as Toshkay and Shark El-Ouainat. Date palm multiplication by transplanting offshoots still remains the best and most common method. Thus, this experiment was carried out to enhance suckers rooting ability and leaf growth of some date palm cultivars by plant growth regulators injection and replanting under greenhouse condition. Suckers of date palm cultivars Sewy, Hayani and Zaghloul, with weights of 2 to $<4 \mathrm{~kg}$ and $4-8 \mathrm{~kg}$, were planted on two dates, (mid of March and September) in each season (2007 and 2008) at the nursery of the Horticulture Research Institute, Agricultural Research Center, Giza, Egypt. All suckers received 9 auxin injection treatments (3 ml)

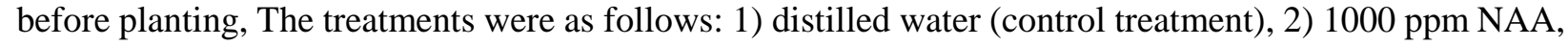
3) 1500 ppm NAA, 4) 2000 ppm NAA, 5) 2500 ppm NAA, 6) 3000 ppm NAA, 7) 1000 ppm IBA, 8) $2000 \mathrm{ppm}$ IBA and 9) $3000 \mathrm{ppm}$ IBA. The obtained results showed that cultivar Hayani has significantly higher roots number/sucker than cultivars Zaghloul and Sewy. The opposite was true concerning root length. Planting in mid March was better than in mid September for all parameters recorded on suckers. Using auxin injection in the suckers proved significantly better survival percentages and means of roots number, length, diameter and length of developed leaves. Moreover, suckers injected with IBA at 3000 ppm or NAA $3000 \mathrm{ppm}$ and planted in mid March recorded the best survival percentages, means of roots number, length and length of developed leaves for date palm cultivars Hayani, Sewy and Zaghloul.
\end{abstract}

Key words: cultivars, date palm, growth regulators, Hayani, IBA, injection, NAA, Phoenix dactylifera, suckers, survival percentage, Sewy, rooting, Zaghloul.

\section{INTRODUCTION}

Date palm, (Phoenix dactylifera L.) is one of the oldest fruit trees in the world and is mentioned in the Holy Qur'an and Bible. Date palm trees are essential components of farming systems in dry and semi arid regions, and can be produced equally well in small farm units and in large scale commercial plantation units. Palm tree is an excellent candidate for cultivation in Egyptian agriculture projects in new reclamation regions, i.e. Toshkay and Shark El-Ouainat. Date palm is propagated commercially by offshoots which are mainly produced in limited numbers during the early life of the tree, depending on the variety and prior fertilizer treatment, irrigation and earthing up around the trunks (Bougeudoura, 1983).
Aerial offshoots (suckers) are usually discarded and rarely used for propagation. However, they should be removed early when they are small in size, possibly to avoid causing a weak point in the mother stem (Al-Obeed, 2005). Rooting capacity has been correlated with some endogenous substances such as carbohydrate content (Reuveni and Adato, 1974) and rooting inhibitors which are found in a number of species. It is suggested that these are a principal reason for rooting failure in certain difficult to rooting cuttings. Offshoots of certain high quality commercial cultivars have been always difficult to root and their survival ability is low (Al-Ghamdi, 1988 and Al-Mana et al., 1996).

El-Hamady et al., (1992) found that small 
offshoots were successfully rooted under the inverted mist system.

Many researchers tried dipping offshoot bases in auxin (IAA, IBA, and NAA) solution to increase their rooting ability (Reuveni and Adato, 1974; Gupta and Godora, 1984; Atalla and Sonbol, 1993; Ismail and Elegaili, 1993; Saidi et al., 1993; Al-Mana et al., 1996; Gasper et al., 1997; Sourour, 2001; Qaddoury \& El-Sayed, 2003 \& 2004; Al-Obeed, 2005; Rizk, 2006 and El-Deeb et al., 2008). El-Hodairi et al. (1992) found that bases of date palm offshoots injected with NAA gave the best rooting response (number, length and dry weight of roots).

The aim of this study was to evaluate the effect of growth regulators injection in enhancing rooting ability and leaf growth of date palm cvs Sewy, Zaghloul and Hayani suckers (aerial offshoots) after removal and replanting under greenhouse conditions.

\section{MATERIALS AND METHODS}

This study was carried out during two successive seasons (2007 and 2008) in a greenhouse at a nursery in the Horticulture Research Institute, Agricultural Research Center, Giza, Egypt. This study was conducted to evaluate the rooting possibility of small date palm offshoots as affected by auxin base injection. Three date palm cultivars were tested, viz. date palm cultivars Sewy, Zaghloul and Hayani. Suckers were separated from each cultivar and divided into two groups according to their weights. The first group was 2 to $<4 \mathrm{~kg}$ and the second was 4-8 kg for each sucker.

All suckers were separated from healthy mother palms aged 10-15 years, during the first and second week of March and September in the two seasons of the study. After suckers separation, they were cleaned by removing the old leaf bases and the fibers surrounding the stem.

The suckers were trimmed to $50 \mathrm{~cm}$ (distance from the base at its widest point to the cut tip) for the first group and to $70 \mathrm{~cm}$ for the second group. Then sucker base surfaces were sterilized by soaking in $10 \%$ Clorox (commercial solution of sodium hypochlorite, $5.25 \%$ active ingredient) containing 2 drops of Tween-20 for 10 minutes. The cut surface of suckers was then rinsed with tap water three times and covered with bitumen. All sucker bases of the three cultivars were exposed to auxin injection treatments using $3 \mathrm{ml} /$ sucker.

Nine auxin injection treatments were applied for the suckers of each group of the three cultivars, as follows: 1) distilled water (control), 2) 1000 ppm NAA, 3) 1500 ppm NAA, 4) 2000 ppm NAA, 5) 2500 ppm NAA, 6) 3000 ppm NAA, 7) 1000 ppm IBA, 8) 2000 ppm IBA and 9) $3000 \mathrm{ppm}$ IBA. Each treatment was represented by three replicates and each replicate included five suckers. The suckers were planted individually in plastic containers sized $50 \times 50 \mathrm{~cm}$ for suckers weighing 2 to $<4 \mathrm{~kg}$ and $75 \times 75 \mathrm{~cm}$ for suckers weighing 4 to $8 \mathrm{~kg}$. All containers were filled with a mixture of peat moss and sand $(1: 1, \mathrm{v} / \mathrm{v})$. The prepared suckers were planted on two dates under greenhouse conditions. The first one was in mid March, and the second was in mid September (in both seasons).

An inverted mist irrigation system provided water for the suckers. Only the bases of the suckers were sprinkled with water automatically for five minutes every hour (El-Hammady et al., 1992). The bases of the suckers were regularly examined. When any sign of infection was visible, it was directly treated with the suitable fungicide. The following data were recorded.

Sucker survival percentage, means of root number, root length $(\mathrm{cm})$, number of newly formed leaves/offshoot and leaf length $(\mathrm{cm})$ were recorded after 12 months from planting in the greenhouse.

Statistical analysis: the obtained data were subjected to analysis of variance. The mean values were compared using LSD method at 5\% level using MSTATC (1987) software package. The data were tabulated and statistically analyzed according to the randomized complete blocks design (Snedecor and Cochran, 1989) with four factors (A: injection treatment, B: cultivar, C: offshoot weight, D: planting date). The percentages were transformed to the arcsine to find the binomial percentages according to Steel and Torrie (1980).

\section{RESULTS AND DISCUSSION}

\subsection{Survival percentage}

Survival percentages were significantly affected by sucker weights, auxin treatment, planting date and the interaction between them within the three date palm cultivars used during the two seasons (Tables $1 \&$ 2). Regarding cultivars, Hayani suckers weighing 4-8 kg gave the highest survival percentage, compared with Zaghloul and Sewy suckers in the two seasons. In addition, the interaction between sucker weight and auxin treatment showed that the highest survival percentage was obtained from suckers weighing 4-8 kg treated with 3000 (93.3\% in the 
Table (1): Effect of auxin injection, sucker weight and planting date on survival percentage for three date palm cultivars during 2007season.

\begin{tabular}{|c|c|c|c|c|c|c|c|c|c|c|c|}
\hline \multirow[t]{2}{*}{$\begin{array}{l}\text { Sucker } \\
\text { Weight }\end{array}$} & \multirow{2}{*}{$\begin{array}{l}\text { Auxin } \\
\text { treatment } \\
(\text { ppm) }\end{array}$} & \multicolumn{2}{|c|}{$\begin{array}{c}\text { Date palm cv. } \\
\text { Sewy }\end{array}$} & \multirow[t]{2}{*}{ Mean } & \multicolumn{2}{|c|}{$\begin{array}{c}\text { Date palm cv. } \\
\text { Zaghloul } \\
\end{array}$} & \multirow[t]{2}{*}{ Mean } & \multicolumn{2}{|c|}{$\begin{array}{c}\text { Date palm cv. } \\
\text { Hayani }\end{array}$} & \multirow[t]{2}{*}{ Mean } & \multirow{2}{*}{$\begin{array}{c}\text { General } \\
\text { mean }\end{array}$} \\
\hline & & March & September & & March & September & & March & September & & \\
\hline \multirow{9}{*}{$\frac{9}{\infty}$} & $\mathrm{CON}$ & 40.6 & 40.6 & 40.4 & 51.8 & 51.4 & 51.6 & 51.8 & 51.4 & 51.6 & 74.8 \\
\hline & 1000NAA & 61.0 & 60.6 & 60.8 & 66.8 & 66.8 & 66.8 & 67.4 & 66.2 & 66.8 & 64.8 \\
\hline & 1500NAA & 64.4 & 61.6 & 63.0 & 68.2 & 68.0 & 68.1 & 75.4 & 67.2 & 71.3 & 67.5 \\
\hline & 2000NAA & 68.6 & 68.4 & 68.5 & 76.0 & 75.6 & 75.8 & 81.4 & 75.6 & 78.5 & 74.3 \\
\hline & 2500NAA & 74.0 & 78.8 & 76.4 & 83.2 & 82.4 & 82.8 & 90.4 & 82.4 & 86.4 & 81.8 \\
\hline & 3000NAA & 88.0 & 87.2 & 87.6 & 86.0 & 92.0 & 89.0 & 95.6 & 93.0 & 94.3 & 90.3 \\
\hline & 1000IBA & 65.4 & 63.0 & 64.2 & 70.6 & 67.4 & 69.0 & 72.4 & 67.4 & 69.9 & 67.7 \\
\hline & 2000IBA & 74.2 & 70.8 & 72.5 & 84.6 & 83.6 & 84.1 & 85.6 & 82.0 & 83.8 & 80.1 \\
\hline & 3000IBA & 90.2 & 86.8 & 88.4 & 96.2 & 95.4 & 95.8 & 98.2 & 95.4 & 96.8 & 93.3 \\
\hline \multicolumn{2}{|l|}{ Mean } & 69.6 & 68.6 & 69.1 & 75.9 & 75.8 & 75.9 & 79.8 & 75.6 & 77.7 & 74.2 \\
\hline \multirow{9}{*}{ 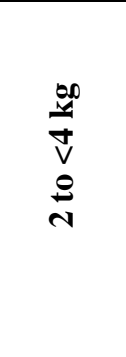 } & CON & 32.8 & 32.6 & 32.7 & 34.6 & 34.0 & 34.3 & 34.0 & 34.0 & 34.0 & 33.7 \\
\hline & 1000NAA & 40.6 & 40.6 & 40.5 & 41.0 & 40.0 & 40.5 & 40.0 & 40.0 & 40.0 & 40.3 \\
\hline & 1500NAA & 45.4 & 45.6 & 45.5 & 46.2 & 45.4 & 45.8 & 49.4 & 47.2 & 48.3 & 46.5 \\
\hline & 2000NAA & 56.8 & 55.4 & 56.1 & 58.2 & 56.8 & 57.5 & 59.4 & 58.6 & 59.0 & 57.5 \\
\hline & 2500NAA & 67.2 & 64.4 & 65.8 & 67.6 & 66.0 & 66.8 & 69.2 & 68.4 & 68.8 & 67.1 \\
\hline & 3000NAA & 77.0 & 72.6 & 74.8 & 74.8 & 74.8 & 74.8 & 76.8 & 75.4 & 76.1 & 75.2 \\
\hline & 1000IBA & 43.4 & 40.4 & 41.9 & 43.8 & 42.4 & 43.1 & 41.8 & 41.2 & 41.5 & 42.2 \\
\hline & 2000IBA & 64.2 & 60.6 & 62.4 & 64.6 & 63.0 & 63.8 & 78.0 & 67.8 & 72.9 & 66.4 \\
\hline & 3000IBA & 77.6 & 75.2 & 76.4 & 77.4 & $\mathbf{7 7 . 0}$ & 77.2 & 79.6 & 78.0 & 78.8 & 77.4 \\
\hline \multicolumn{2}{|c|}{ Mean } & 56.1 & 54.1 & 55.1 & 56.5 & 55.5 & 56.0 & 58.7 & 56.7 & 57.7 & 56.3 \\
\hline \multicolumn{2}{|c|}{ General mean } & 62.8 & 61.4 & 62.1 & 66.2 & 65.7 & 65.9 & 69.2 & 66.2 & 67.7 & \\
\hline & $\begin{array}{c}\text { L.S.D. } \\
\text { Auxin } \\
\text { Cultiva } \\
\text { Offsho } \\
\text { Plantin } \\
\text { B } \times D=0\end{array}$ & $\begin{array}{l}\text { t } 0.05 \text { for } \\
\text { eatment (A) } \\
\text { (B) } \\
\text { weight }(C) \\
\text { date }(D) \\
\end{array}$ & $\begin{array}{l}=0 . \\
=0 . \\
=0 .\end{array}$ & & $\begin{array}{l}B=1.70 \\
C=1.44 \\
D=1.44 \\
C=0.83\end{array}$ & $\begin{array}{l}\mathbf{A} \times \mathbf{B} \times \mathbf{C} \\
\mathbf{A} \times \mathbf{B} \times \mathbf{D} \\
\mathbf{A} \times \mathbf{C} \times \mathbf{D} \\
\mathbf{A} \times \mathbf{B} \times \mathbf{C}\end{array}$ & $\begin{array}{l}19 \\
19 \\
=3.5\end{array}$ & & & & \\
\hline
\end{tabular}


Table (2): Effect of auxin injection, sucker weight and planting date on survival percentage for three date palm cultivars during second season 2008.

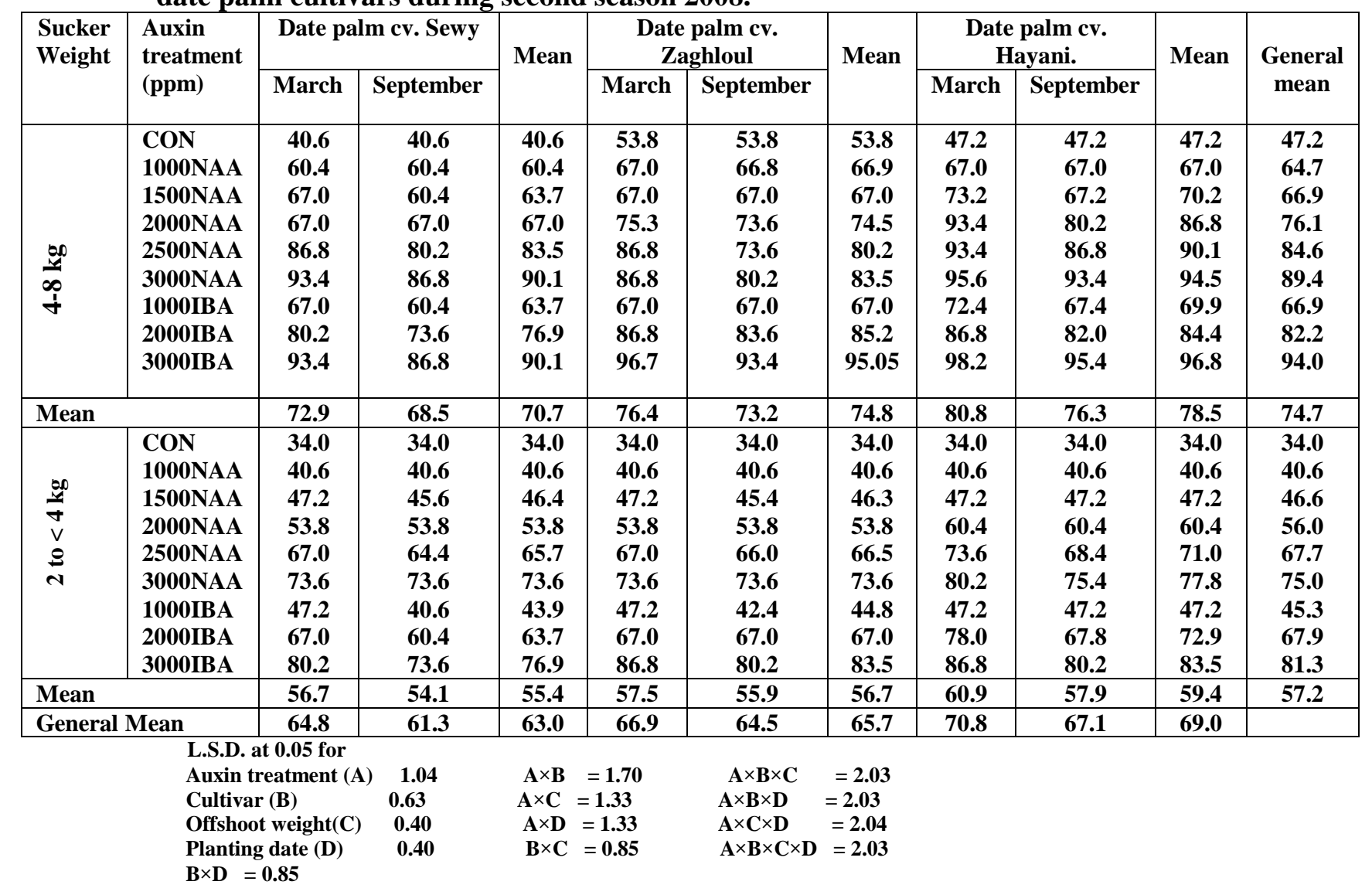


first and $94.0 \%$ in the second season )comparing with the other interactions.

Regarding the interaction between sucker weight, cultivar and planting date, Date palm cv. Hayani suckers weighing 4-8 kg planted in March had the highest survival percentage $(79.8 \%$ and $80.8 \%$ in the first and second seasons, respectively) compared with the other interactions in the two seasons. Moreover, Hayani suckers produced the highest general mean for survival percentage when planted in March $(69.2 \%$ and $70.8 \%$ the first and second seasons) compared with other interactions in this regard.

In addition, the interaction between sucker weight, auxin treatment and cultivars showed that Date palm cv. Hayani suckers weighing $4-8 \mathrm{~kg}$ treated with IBA at $3000 \mathrm{ppm}$ gave the highest survival percentage at 12 months after planting comparing with the other interactions.

Concerning the interaction between the four studied factors (sucker weight, treatment injection, cultivars and planting date), the result proved that date palm cv Hayani suckers weighing 4-8 kg planted in March had the highest survival percentage when injected with $3000 \mathrm{ppm}$ IBA compared with the other interactions in this respect during the two seasons.

It can be observed that the most effective treatment affecting survival percentage was 3000 ppm IBA using suckers weighing 4-8 $\mathrm{kg}$ and planting in March. Using injection treatments with aerial offshoots (suckers) weighing 2 to $<4 \mathrm{~kg}$ increased survival percentage, and the feasibility of using this weight in date palm vegetative propagation. These results may be due to amount of nutrients inside the bulbs of the heaviest suckers compared with the lightest in weight ones, or to the ability of the heaviest suckers to maintain in life until new roots initiation (AlObeed, 2005; Rizk, 2006 and El-Deeb et al., 2008).

\subsection{Roots number}

Root numbers were significantly affected by sucker weight, auxin treatment, planting date and the interaction between them for the three date palm cultivars used during the two seasons. Suckers weighing 4-8 $\mathrm{kg}$ recorded a higher roots number than suckers weighing 2 to $<4 \mathrm{~kg}$ at 12 months after planting in the two seasons (Tables 3 and 4).

The interaction between suckers weight and cultivar revealed that Hayani suckers weighing 4$8 \mathrm{~kg}$ gave the highest root number compared with Zaghloul and Sewy suckers in the two seasons. In addition, the interaction between suckers weight and auxin treatment showed that the highest suckers roots number was obtained from suckers weighing $4-8 \mathrm{~kg}$ treated with $3000 \mathrm{ppm}$ NAA (29.6 in the first season and 31.3 in the second season) compared with the other interactions in this trial.

Regarding the interaction between sucker weight, cultivar and planting date, date palm cv. Hayani suckers weighing 4-8 kg planted in March produced the highest roots number (30.7 and 31.5) compared with the other interactions in the first and second seasons, respectively. Date palm cv. Hayani suckers produced the highest roots number when planted in March comparing with other interactions in this regard during the two seasons.

In addition, the interaction between sucker weight, auxin treatment and cultivars revealed that Hayani suckers $(4-8 \mathrm{~kg})$ injected with $3000 \mathrm{ppm}$ NAA the highest roots number at 12 months after planting compared with the other interactions. Also, in respect to suckers weighing $2-4 \mathrm{~kg}$ date palm cv. Hayani injected with NAA at 3000 ppm produced the highest roots number compared with the other interactions in both seasons. It was clearly noticed that injection using $3000 \mathrm{ppm}$ of either NAA or IBA gave insignificantly different results of roots number during the two seasons.

Concerning the interaction between sucker weight, treatment injection, cultivars and planting date, the recorded result show that Hayani suckers weighing 4-8 $\mathrm{kg}$ planted in March produced the highest roots number when injected with 3000 ppm NAA compared with the other interactions in this respect during the two seasons.

\subsection{Root length $(\mathrm{cm})$}

Root length was significantly affected by sucker weight, auxin treatment, planting date and the interaction between them within the three tested date palm cultivars during the two seasons.

The heaviest suckers $(4-8 \mathrm{~kg})$ recorded the highest root length at 12 months after planting, compared with suckers weighing 2 to $<4 \mathrm{~kg}$ in the two seasons (Tables $5 \& 6$ ). Hayani date palm suckers gave the highest root length compared with Zaghloul and Sewy. In addition, IBA treatments gave generally longer roots after planting than NAA in both seasons. The interaction between sucker weight and auxin treatment showed that the highest root length was obtained from suckers weighing $4-8 \mathrm{~kg}$ treated with $3000 \mathrm{ppm}$ IBA (25.2 $\mathrm{cm}$ and $26.0 \mathrm{~cm}$ in the first and second seasons, respectively) compared with the other interactions.

Regarding the interaction between sucker weight, cultivar and planting date, date palm cv. Hayani suckers weighing 4-8 kg planted in March 
Table (3): Effect of auxin injection, sucker weight and planting date on roots number for three date palm cultivars during the first season (2007).

\begin{tabular}{|c|c|c|c|c|c|c|c|c|c|c|c|}
\hline \multirow{2}{*}{$\begin{array}{l}\text { Sucker } \\
\text { Weight }\end{array}$} & \multirow{2}{*}{$\begin{array}{c}\text { Auxin } \\
\text { treatment }\end{array}$} & \multicolumn{2}{|c|}{$\begin{array}{l}\text { Date palm cv. } \\
\text { Sewy }\end{array}$} & \multirow{2}{*}{ Mean } & \multicolumn{2}{|c|}{$\begin{array}{c}\text { Date palm cv. } \\
\text { Zaghloul }\end{array}$} & \multirow[t]{2}{*}{ Mean } & \multicolumn{2}{|c|}{$\begin{array}{l}\text { Date palm cv. } \\
\text { Hayani }\end{array}$} & \multirow{2}{*}{ Mean } & \multirow[t]{2}{*}{$\begin{array}{l}\text { General } \\
\text { mean }\end{array}$} \\
\hline & & March & September & & March & September & & March & September & & \\
\hline $\begin{array}{l}00 \\
\frac{1}{\infty} \\
1 \\
1\end{array}$ & $\begin{array}{l}\text { CON } \\
1000 N A A \\
1500 N A A \\
2000 N A A \\
2500 N A A \\
\text { 3000NAA } \\
1000 I B A \\
\text { 2000IBA } \\
\text { 3000IBA } \\
\end{array}$ & $\begin{array}{l}14.0 \\
15.2 \\
15.6 \\
16.8 \\
17.4 \\
19.9 \\
16.4 \\
16.8 \\
19.3 \\
\end{array}$ & $\begin{array}{l}13.0 \\
14.4 \\
14.8 \\
16.4 \\
14.6 \\
19.3 \\
14.2 \\
15.8 \\
18.8 \\
\end{array}$ & $\begin{array}{l}13.5 \\
14.8 \\
15.2 \\
16.6 \\
16.0 \\
19.6 \\
15.3 \\
16.3 \\
19.0\end{array}$ & $\begin{array}{l}15.0 \\
21.0 \\
26.0 \\
33.0 \\
33.6 \\
35.0 \\
23.0 \\
\mathbf{3 4 . 2} \\
\mathbf{3 4 . 0} \\
\end{array}$ & $\begin{array}{l}14.0 \\
22.0 \\
27.0 \\
32.8 \\
31.4 \\
32.4 \\
23.6 \\
30.0 \\
32.2 \\
\end{array}$ & $\begin{array}{l}14.5 \\
21.5 \\
26.5 \\
32.9 \\
32.5 \\
33.7 \\
23.3 \\
32.1 \\
33.1 \\
\end{array}$ & $\begin{array}{l}17.2 \\
26.8 \\
28.6 \\
34.0 \\
34.4 \\
36.2 \\
28.0 \\
35.4 \\
36.0 \\
\end{array}$ & $\begin{array}{l}15.3 \\
26.0 \\
27.2 \\
33.8 \\
33.6 \\
34.8 \\
27.0 \\
34.4 \\
33.8 \\
\end{array}$ & $\begin{array}{l}16.3 \\
26.4 \\
27.9 \\
33.9 \\
34.0 \\
35.5 \\
27.5 \\
34.9 \\
34.9 \\
\end{array}$ & $\begin{array}{l}14.7 \\
20.9 \\
23.2 \\
27.8 \\
27.5 \\
29.6 \\
22.0 \\
27.7 \\
29.0 \\
\end{array}$ \\
\hline \multicolumn{2}{|l|}{ Mean } & 16.8 & 15.7 & 16.3 & 28.3 & 27.3 & 27.8 & 30.7 & 29.5 & 30.1 & 24.7 \\
\hline \multicolumn{2}{|c|}{ Mean } & 9.7 & 9.4 & 9.5 & 11.3 & 11.1 & 11.2 & 11.6 & 11.2 & 11.4 & 10.7 \\
\hline \multicolumn{2}{|c|}{ General mean } & 13.3 & 12.6 & 12.9 & 19.7 & 19.2 & 19.5 & 21.2 & 20.4 & 20.8 & \\
\hline & $\begin{array}{c}\text { L.S.D. at } \\
\text { Auxin t } \\
\text { Cultiva } \\
\text { Offshoo } \\
\text { Planting } \\
B \times D=\end{array}$ & $\begin{array}{l}0.05 \text { for } \\
\text { eatment (A } \\
\text { (B) } \\
\text { s weight (C } \\
\text { date(D) } \\
0.76\end{array}$ & $\begin{array}{c}=0.93 \\
=0.54 \\
=0.44 \\
=0.44\end{array}$ & $\begin{array}{r}A \times B=1.6 \\
A \times C= \\
A \times D=1 . \\
B \times C=\end{array}$ & & $\begin{array}{c}\mathbf{A} \times \mathbf{B} \times \mathbf{C}=\mathbf{2} \\
\mathbf{A} \times \mathbf{B} \times \mathbf{D} \\
\mathbf{A} \times \mathbf{C} \times \mathbf{D} \\
\mathbf{A} \times \mathbf{B} \times \mathbf{C} \times 1\end{array}$ & $\begin{array}{l}.29 \\
=2.29 \\
=1.87 \\
D=2.23\end{array}$ & & & & \\
\hline
\end{tabular}


Table (4): Effect of auxin injection, suckers weight and planting date on roots number for three date palm cultivars during the second season 2008.

\begin{tabular}{|c|c|c|c|c|c|c|c|c|c|c|c|}
\hline \multirow{2}{*}{$\begin{array}{r}\text { Sucker } \\
\text { Weight }\end{array}$} & \multirow{2}{*}{$\begin{array}{l}\text { Auxin } \\
\text { treatment }\end{array}$} & \multicolumn{2}{|c|}{$\begin{array}{c}\text { Date palm cv. } \\
\text { Sewy }\end{array}$} & \multirow[t]{2}{*}{ Mean } & \multicolumn{2}{|c|}{$\begin{array}{c}\text { Date palm cv. } \\
\text { Zaghloul }\end{array}$} & \multirow[t]{2}{*}{ Mean } & \multicolumn{2}{|c|}{$\begin{array}{c}\text { Date palm cv. } \\
\text { Hayani }\end{array}$} & \multirow[t]{2}{*}{ Mean } & \multirow[t]{2}{*}{$\begin{array}{l}\text { General } \\
\text { mean }\end{array}$} \\
\hline & & March & September & & March & September & & March & September & & \\
\hline \multicolumn{2}{|c|}{ Mean } & 17.1 & 16.7 & 16.9 & 30.1 & 29.6 & 29.9 & 31.5 & 30.8 & 31.2 & 26.0 \\
\hline 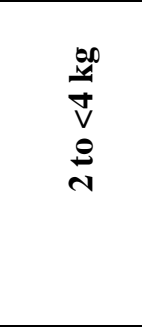 & $\begin{array}{c}\text { CON } \\
\text { 1000NAA } \\
\text { 1500NAA } \\
2000 N A A \\
\text { 2500NAA } \\
\text { 3000NAA } \\
\text { 1000IBA } \\
\text { 2000IBA } \\
\text { 3000IBA } \\
\end{array}$ & \begin{tabular}{|c|}
8.2 \\
8.5 \\
8.8 \\
10.1 \\
10.4 \\
12.5 \\
9.8 \\
10.6 \\
12.3 \\
\end{tabular} & \begin{tabular}{c|}
8.0 \\
8.2 \\
8.5 \\
9.9 \\
10.3 \\
11.4 \\
9.5 \\
10.3 \\
11.3 \\
\end{tabular} & \begin{tabular}{c|}
8.1 \\
8.4 \\
8.7 \\
10.0 \\
10.4 \\
12.0 \\
9.7 \\
10.5 \\
11.8 \\
\end{tabular} & \begin{tabular}{|c|}
9.2 \\
9.5 \\
9.6 \\
9.8 \\
13.5 \\
14.7 \\
10.5 \\
13.7 \\
14.5 \\
\end{tabular} & \begin{tabular}{|c|}
9.1 \\
9.4 \\
9.4 \\
9.8 \\
13.1 \\
13.6 \\
10.2 \\
13.4 \\
13.9 \\
\end{tabular} & \begin{tabular}{|l|}
9.2 \\
9.5 \\
9.5 \\
9.8 \\
13.3 \\
14.2 \\
10.4 \\
13.6 \\
14.2 \\
\end{tabular} & \begin{tabular}{|c|}
9.3 \\
9.7 \\
9.8 \\
12.7 \\
13.9 \\
14.9 \\
10.6 \\
12.4 \\
14.7 \\
\end{tabular} & \begin{tabular}{|c|}
9.1 \\
9.5 \\
9.6 \\
12.4 \\
13.2 \\
14.3 \\
10.2 \\
11.6 \\
14.1 \\
\end{tabular} & \begin{tabular}{|c|}
9.2 \\
9.6 \\
9.7 \\
12.5 \\
13.5 \\
14.6 \\
10.4 \\
12.0 \\
14.4 \\
\end{tabular} & $\begin{array}{l}08.8 \\
09.1 \\
09.3 \\
10.8 \\
12.4 \\
13.5 \\
10.1 \\
12.0 \\
13.4 \\
\end{array}$ \\
\hline \multicolumn{2}{|c|}{ Mean } & 10.2 & 9.7 & 9.9 & 11.7 & 11.3 & 11.5 & 12.0 & 11.5 & 11.8 & 11.0 \\
\hline \multicolumn{2}{|c|}{ General mean } & 13.6 & 13.3 & 13.4 & 20.9 & 20.5 & 20.7 & 21.7 & 21.2 & 21.5 & \\
\hline \multicolumn{12}{|c|}{$\begin{array}{ll}\text { LSD at } 0.05 \text { for } & \\
\text { Auxin treatment }(A) & =0.95 \\
\text { Cultivar }(B) & =0.58 \\
\text { Offshoots weight }(C) & =0.49 \\
\text { Planting date }(D) & =\mathbf{0 . 4 9}\end{array}$} \\
\hline
\end{tabular}


Table (5): Effect of auxin treatment, sucker weight and planting date on root length for three cultivars of date palm during 2007 season.

\begin{tabular}{|c|c|c|c|c|c|c|c|c|c|c|c|}
\hline \multirow[t]{2}{*}{$\begin{array}{l}\text { Sucker } \\
\text { Weight }\end{array}$} & \multirow{2}{*}{$\begin{array}{l}\text { Auxin } \\
\text { treatment }\end{array}$} & \multicolumn{2}{|c|}{$\begin{array}{c}\text { Date palm cv. } \\
\text { Sewy }\end{array}$} & \multirow[t]{2}{*}{ Mean } & \multicolumn{2}{|c|}{$\begin{array}{c}\text { Date palm cv. } \\
\text { Zaghloul }\end{array}$} & \multirow[t]{2}{*}{ Mean } & \multicolumn{2}{|c|}{$\begin{array}{c}\text { Date palm cv. } \\
\text { Hayani }\end{array}$} & \multirow[t]{2}{*}{ Mean } & \multirow{2}{*}{$\begin{array}{c}\text { Genera } \\
\text { mean }\end{array}$} \\
\hline & & March & September & & March & September & & March & September & & \\
\hline $\begin{array}{l}00 \\
\frac{0}{\infty} \\
\dot{f} \\
\dot{f}\end{array}$ & $\begin{array}{l}\text { CON } \\
\text { 1000NAA } \\
\text { 1500NAA } \\
\text { 2000NAA } \\
\text { 2500NAA } \\
\text { 3000NAA } \\
\text { 1000IBA } \\
\text { 2000IBA } \\
\text { 3000IBA }\end{array}$ & \begin{tabular}{c|}
8.7 \\
21.6 \\
21.3 \\
22.2 \\
21.8 \\
23.8 \\
21.3 \\
22.4 \\
24.1
\end{tabular} & \begin{tabular}{|c|}
8.5 \\
17.7 \\
19.7 \\
20.3 \\
21.5 \\
23.7 \\
20.8 \\
22.4 \\
23.9
\end{tabular} & \begin{tabular}{|c|}
8.4 \\
19.6 \\
20.5 \\
21.3 \\
21.6 \\
23.7 \\
21.1 \\
21.5 \\
24.0
\end{tabular} & \begin{tabular}{|l|}
10.1 \\
21.3 \\
21.7 \\
24.0 \\
24.2 \\
25.4 \\
22.6 \\
25.0 \\
27.1
\end{tabular} & \begin{tabular}{l|}
10.0 \\
21.8 \\
22.7 \\
22.9 \\
22.1 \\
22.9 \\
21.8 \\
22.2 \\
22.1
\end{tabular} & \begin{tabular}{|l|}
10.1 \\
21.5 \\
22.2 \\
23.9 \\
32.1 \\
24.1 \\
22.2 \\
32.1 \\
24.6
\end{tabular} & \begin{tabular}{|c|}
9.3 \\
23.1 \\
23.4 \\
25.4 \\
25.4 \\
26.7 \\
22.2 \\
25.4 \\
28.3 \\
\end{tabular} & \begin{tabular}{|c|}
9.6 \\
21.9 \\
21.9 \\
24.2 \\
23.1 \\
24.0 \\
22.1 \\
23.3 \\
25.7
\end{tabular} & \begin{tabular}{|c|}
9.4 \\
22.5 \\
22.6 \\
24.8 \\
24.3 \\
25.3 \\
33.1 \\
24.3 \\
27.0
\end{tabular} & \begin{tabular}{|c|}
9.3 \\
21.2 \\
21.8 \\
23.3 \\
23.0 \\
24.4 \\
22.1 \\
23.0 \\
25.2
\end{tabular} \\
\hline \multicolumn{2}{|l|}{ Mean } & 20.5 & 19.9 & 20.2 & 22.4 & 20.9 & 21.7 & 23.2 & 21.7 & 22.6 & 21.5 \\
\hline 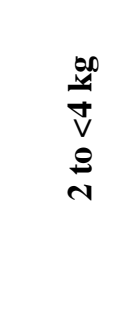 & $\begin{array}{l}\text { CON } \\
1000 N A A \\
1500 N A A \\
2000 N A A \\
\text { 2500NAA } \\
\text { 3000NAA } \\
\text { 1000IBA } \\
\text { 2000IBA } \\
\text { 3000IBA }\end{array}$ & \begin{tabular}{|c|}
9.5 \\
10.5 \\
10.6 \\
12.2 \\
12.6 \\
13.1 \\
11.8 \\
12.8 \\
13.2
\end{tabular} & \begin{tabular}{|c|}
5.7 \\
8.3 \\
10.4 \\
12.0 \\
12.5 \\
12.7 \\
11.6 \\
11.8 \\
13.1
\end{tabular} & \begin{tabular}{|c|}
7.6 \\
9.4 \\
10.5 \\
12.1 \\
12.6 \\
12.9 \\
11.7 \\
12.7 \\
13.1
\end{tabular} & \begin{tabular}{|c|}
6.7 \\
8.1 \\
10.8 \\
10.7 \\
11.6 \\
12.6 \\
9.8 \\
11.6 \\
13.0
\end{tabular} & $\begin{array}{l}10.3 \\
10.9 \\
11.0 \\
11.1 \\
11.7 \\
11.7 \\
10.8 \\
12.6 \\
12.6\end{array}$ & \begin{tabular}{|c|}
8.5 \\
9.4 \\
10.9 \\
10.9 \\
11.6 \\
12.5 \\
10.3 \\
11.6 \\
12.8
\end{tabular} & \begin{tabular}{|c|c|}
7.2 & \\
10.4 & 10.9 \\
11.5 & 11.9 \\
12.6 & \\
10.7 & 12.4 \\
13.3 &
\end{tabular} & \begin{tabular}{l|l|}
10.1 & \\
11.0 & 11.4 \\
11.6 & 12.4 \\
13.2 & \\
11.1 & 12.8 \\
13.5 &
\end{tabular} & \begin{tabular}{l|l|}
08.6 & \\
10.7 & 11.1 \\
11.6 & 12.1 \\
12.9 & \\
10.9 \\
12.6
\end{tabular} & \begin{tabular}{|l|l|}
08.3 & 09.8 \\
10.8 & 11.5 \\
12.1 & 12.7 \\
10.9 \\
12.4 \\
13.1
\end{tabular} \\
\hline \multirow{2}{*}{\multicolumn{2}{|c|}{$\begin{array}{l}\text { Mean } \\
\text { Gener: }\end{array}$}} & 11.8 & 11.0 & 11.4 & 11.4 & 10.5 & 10.9 & 11.9 & 11.2 & 11.5 & 11.3 \\
\hline & & 16.1 & 15.4 & 15.8 & 16.4 & 16.2 & 16.3 & 17.2 & 16.9 & 17.1 & \\
\hline
\end{tabular}


Table (6): Effect of auxin treatment, sucker weight and planting date on root length for three cultivars of date palm during 2008 season..

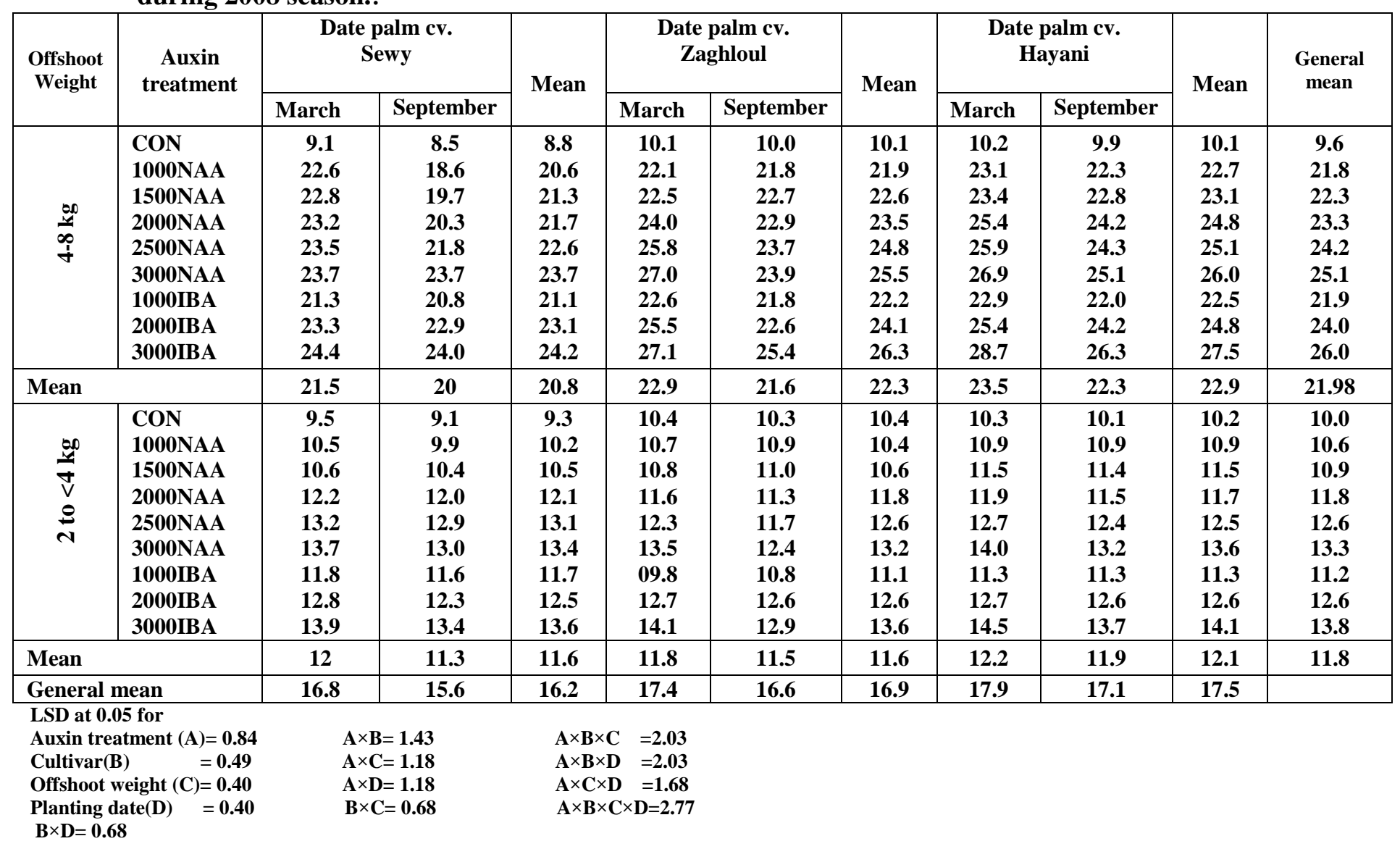


produced the highest root length $(23.2 \mathrm{~cm}$ and 23.5 $\mathrm{cm})$ compared with the other interactions in the first and second seasons. The interaction between cultivars and planting date proved that planting in March increased root length for date palm cv. Hayani comparing with the other interactions in this respect in the two seasons.

In addition, the interaction between suckers weight, auxin treatment and cultivars indicated that date palm $\mathrm{cv}$. Hayani suckers weighing 4-8 kg injected by $3000 \mathrm{ppm}$ IBA gave the highest root length compared with the other interactions. Using auxin injection in the sucker bases significantly increased rooting percentage and means of root number, length, and diameter. Moreover, injecting suckers with IBA or NAA at $3000 \mathrm{ppm}$ and planting in mid March increased rooting percentage of date palm cvs. Sewy, Zaghloul and Hayani and mean roots number, length and diameter. These results are in parallel with those of Atalla and Sonbol (1993), Saidi et al. (1993), Lavee et al. (1994), Al-Mana et al. (1996), Rizk and El-Sayed (2003), Qaddory and Amssa (2003 \& 2004), Al-Obeed (2005), Rizk (2006), El-Deeb et al. (2008) and El-Kosary (2009).

\subsection{Number of newly formed leaves}

Data in Tables $(7 \& 8)$ show that number of newly formed leaves was significantly affected by suckers weight, auxin treatment, cultivar, planting date and the interaction between them. The heaviest suckers (4-8 kg) recorded the highest number of newly formed leaves compared with suckers weighing 2 to $<4 \mathrm{~kg}$ in the two seasons.

The interaction between suckers weight and cultivar revealed that Hayani suckers weighing 4$8 \mathrm{~kg}$ gave the highest number of newly formed leaves compared with Zaghloul and Sewy suckers in the first seasons. In addition, the interaction between sucker weight and auxin treatment showed that the highest number of newly formed leaves was obtained from suckers weighing $4-8 \mathrm{~kg}$ treated with 3000 ppm NAA (5.7 and 5.8 leaves in the first and second seasons) compared with the other interactions in this trial.

Regarding the interaction between sucker weight, cultivar and planting date, date palm cv. Hayani suckers weighing 4-8 kg planted in March produced the highest number of newly formed leaves (5.5 in both seasons) comparing with the other interactions in the two seasons. In addition, the interaction between sucker weight, auxin treatment and cultivars revealed that Hayani suckers weighing 4-8 $\mathrm{kg}$ and treated with NAA at $3000 \mathrm{ppm}$ gave the highest number of newly formed leaves compared with the other interactions.

Referring to the interaction between sucker weight, auxin injection, cultivars and planting date, it is clear that date palm cv. Hayani suckers weighing 4-8 $\mathrm{kg}$ produced the highest number of newly formed leaves when planted in March and injected with 3000 ppm NAA compared with other interactions in the the first season while in the second one, Hyani and Zaghloul gave the same number of leaves. ( no signification different between the two cultivars).

\subsection{Length of developed leaves}

Mean length of developed leaves was significantly affected by sucker weight, auxin treatment, planting date and the interaction between them within the three date palm cultivars used during the two seasons (Tables $9 \& 10$ ).

Zaghloul date palm suckers weighing $4-8 \mathrm{~kg}$ gave the highest mean length of developed leaves compared with Hayani and Sewy suckers in the two seasons.

In addition, the interaction between suckers weight and auxin treatment showed that the highest mean length of leaves was obtained from suckers weighing 4-8 $\mathrm{kg}$ treated by $3000 \mathrm{ppm}$ NAA $(115.6 \mathrm{~cm}$ and $116.3 \mathrm{~cm}$ in the first and second seasons) compared with the other interactions in this trial. Regarding the interaction between sucker weight, cultivar and planting date, Zaghloul suckers weighing 4-8 $\mathrm{kg}$ planted in March produced the highest mean length of leaves $(110.1 \mathrm{~cm}$ and $109.0 \mathrm{~cm})$ compared with the other interactions in both seasons.

The interaction between sucker weight, auxin injection, cultivars and planting date showed that Zaghloul suckers weighing 4-8 kg planted in March produced the highest length of developed leaves when injected with 3000 ppm NAA compared with the other interactions in this respect during the two seasons.

These results are in agreement with Ismail and Elegaili (1993), Al-Mana et al. (1996), Qaddoury and Amssa (2003 \& 2004), Rizk and El-Sayed (2003), and El-Kosary (2009). They found that the best rooting response was obtained with NAA or IBA treatments. Auxin increased the number of leaves and the length of the leaves.

Hayani suckers formed significantly more roots than Sewy and Zaghloul, whereas Zaghloul produced taller leaves than Hayani and Sewy. These results are in accordance with Dawoud (2001) and Rizk and El-Sayed (2003). They found that offshoot rooting was significantly affected by cultivar. 
Table (7): Effect of auxin injection, sucker weight and planting date on number of newly formed leaves on suckers of three date palm cultivars during 2007 season.

\begin{tabular}{|c|c|c|c|c|c|c|c|c|c|c|c|}
\hline \multirow{2}{*}{$\begin{array}{l}\text { Sucker } \\
\text { Weight }\end{array}$} & \multirow{2}{*}{$\begin{array}{c}\text { Auxin } \\
\text { treatment }\end{array}$} & \multicolumn{2}{|c|}{$\begin{array}{c}\text { Date palmev. } \\
\text { Sewy }\end{array}$} & \multirow[t]{2}{*}{ Mean } & \multicolumn{2}{|c|}{$\begin{array}{c}\text { Date palm cv. } \\
\text { Zaghloul }\end{array}$} & \multirow[t]{2}{*}{ Mean } & \multicolumn{2}{|c|}{$\begin{array}{l}\text { Date palm cv. } \\
\text { Hayani }\end{array}$} & \multirow[t]{2}{*}{ Mean } & \multirow{2}{*}{$\begin{array}{r}\text { General } \\
\text { mean }\end{array}$} \\
\hline & & March & September & & March & September & & March & September & & \\
\hline \multirow{9}{*}{ 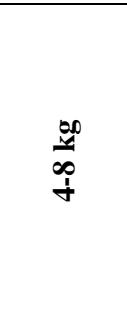 } & CON & 2.8 & 2.8 & 2.8 & 3.2 & 3.1 & 3.1 & 3.3 & 3.2 & 3.2 & 3.0 \\
\hline & 1000NAA & 4.2 & 4.0 & 4.1 & 5.6 & 4.8 & 5.2 & 5.4 & 4.8 & 5.1 & 4.8 \\
\hline & 1500NAA & 4.8 & 4.8 & 4.8 & 5.4 & 4.8 & 5.2 & 5.6 & 4.8 & 5.1 & 5.0 \\
\hline & 2000NAA & 5.6 & 5.0 & 5.3 & 5.6 & 5.6 & 5.7 & 5.8 & 5.4 & 5.5 & 5.5 \\
\hline & 2500NAA & 5.6 & 5.2 & 5.4 & 5.6 & 5.6 & 5.7 & 5.8 & 5.4 & 5.5 & 5.5 \\
\hline & 3000NAA & 5.6 & 5.4 & 5.5 & 6.0 & 5.8 & 5.9 & 6.0 & 5.6 & 5.8 & 5.7 \\
\hline & 1000IBA & 4.6 & 4.2 & 4.4 & 5.4 & 4.4 & 4.9 & 5.2 & 4.4 & 4.8 & 4.7 \\
\hline & 2000IBA & 5.0 & 4.8 & 4.9 & 5.4 & 5.0 & 5.5 & 6.0 & 4.8 & 5.1 & 5.2 \\
\hline & 3000IBA & 5.2 & 5.0 & 5.1 & 6.0 & 5.4 & 5.7 & 6.0 & 5.2 & 5.6 & 5.5 \\
\hline \multicolumn{2}{|l|}{ Mean } & 4.8 & 4.6 & 4.7 & 5.3 & 4.9 & 5.1 & 5.5 & 4.9 & 5.2 & 5.0 \\
\hline \multirow{9}{*}{ 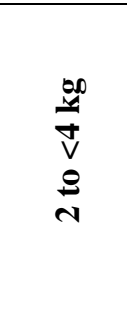 } & CON & 2.0 & 2.0 & 2.0 & 2.4 & 2.4 & 2.4 & 2.2 & 2.2 & 2.2 & 2.2 \\
\hline & 1000NAA & 3.0 & 3.0 & 3.0 & 3.0 & 3.0 & 3.0 & 3.2 & 3.0 & 3.1 & 3.0 \\
\hline & 1500NAA & 3.6 & 3.4 & 3.5 & 3.0 & 3.0 & 3.0 & 3.8 & 3.8 & 3.8 & 3.4 \\
\hline & 2000NAA & 3.6 & 3.4 & 3.5 & 3.8 & 4.0 & 3.9 & 3.9 & 3.8 & 3.85 & 3.8 \\
\hline & 2500NAA & 3.6 & 3.6 & 3.6 & 4.0 & 4.0 & 4.0 & 3.9 & 3.8 & 3.85 & 3.8 \\
\hline & 3000NAA & 3.7 & 3.6 & 3.6 & 4.2 & 4.2 & 4.2 & 4.4 & 4.4 & 4.4 & 4.1 \\
\hline & 1000IBA & 3.6 & 3.4 & 3.5 & 3.4 & 3.4 & 3.4 & 3.4 & 3.4 & 3.4 & 3.4 \\
\hline & 2000IBA & 4.0 & 4.0 & 4.0 & 3.6 & 3.6 & 3.6 & 3.8 & 3.8 & 3.8 & 3.8 \\
\hline & 3000IBA & 4.0 & 4.0 & 4.0 & 4.0 & 4.0 & 4.0 & 4.0 & 4.0 & 4.0 & 4.0 \\
\hline \multicolumn{2}{|l|}{ Mean } & 3.5 & 3.3 & 3.4 & 3.5 & 3.5 & 3.5 & 3.6 & 3.6 & 3.6 & 3.5 \\
\hline \multicolumn{2}{|c|}{ General Mean } & 4.1 & 3.9 & 4.0 & 4.5 & 4.3 & 4.4 & 4.6 & 4.2 & 4.4 & \\
\hline \multicolumn{12}{|c|}{$\begin{array}{l}\text { L.S.D. at } 0.05 \text { for } \\
\text { Auxin treatment }(A)=0.30\end{array}$} \\
\hline \multicolumn{2}{|c|}{ Cultivar (B) } & 0.17 & $\mathrm{~A} \times \mathrm{C}=\mathbf{0 . 4 3}$ & & $\mathbf{A} \times \mathbf{B} \times \mathbf{D}=$ & & & & & & \\
\hline \multicolumn{2}{|c|}{ Offshoots weight } & & $\mathrm{A} \times \mathrm{D}=\mathbf{0 . 4 3}$ & & $\mathbf{A} \times \mathbf{C} \times \mathbf{D}=$ & & & & & & \\
\hline \multirow{2}{*}{\multicolumn{2}{|c|}{$\begin{array}{l}\text { Planting date }(D)= \\
B \times D=0.25\end{array}$}} & & $\mathrm{~B} \times \mathrm{C}=\mathbf{0 . 2 5}$ & & $\mathbf{A} \times \mathbf{B} \times \mathbf{C} \times$ & $=1.06$ & & & & & \\
\hline & & $\times \mathrm{D}=\mathbf{0 . 2 5}$ & & & & & & & & & \\
\hline
\end{tabular}


Table (8): Effect of auxin injection, sucker weight and planting date on number of newly formed leaves on suckers of three date palm cultivars during 2008 season.

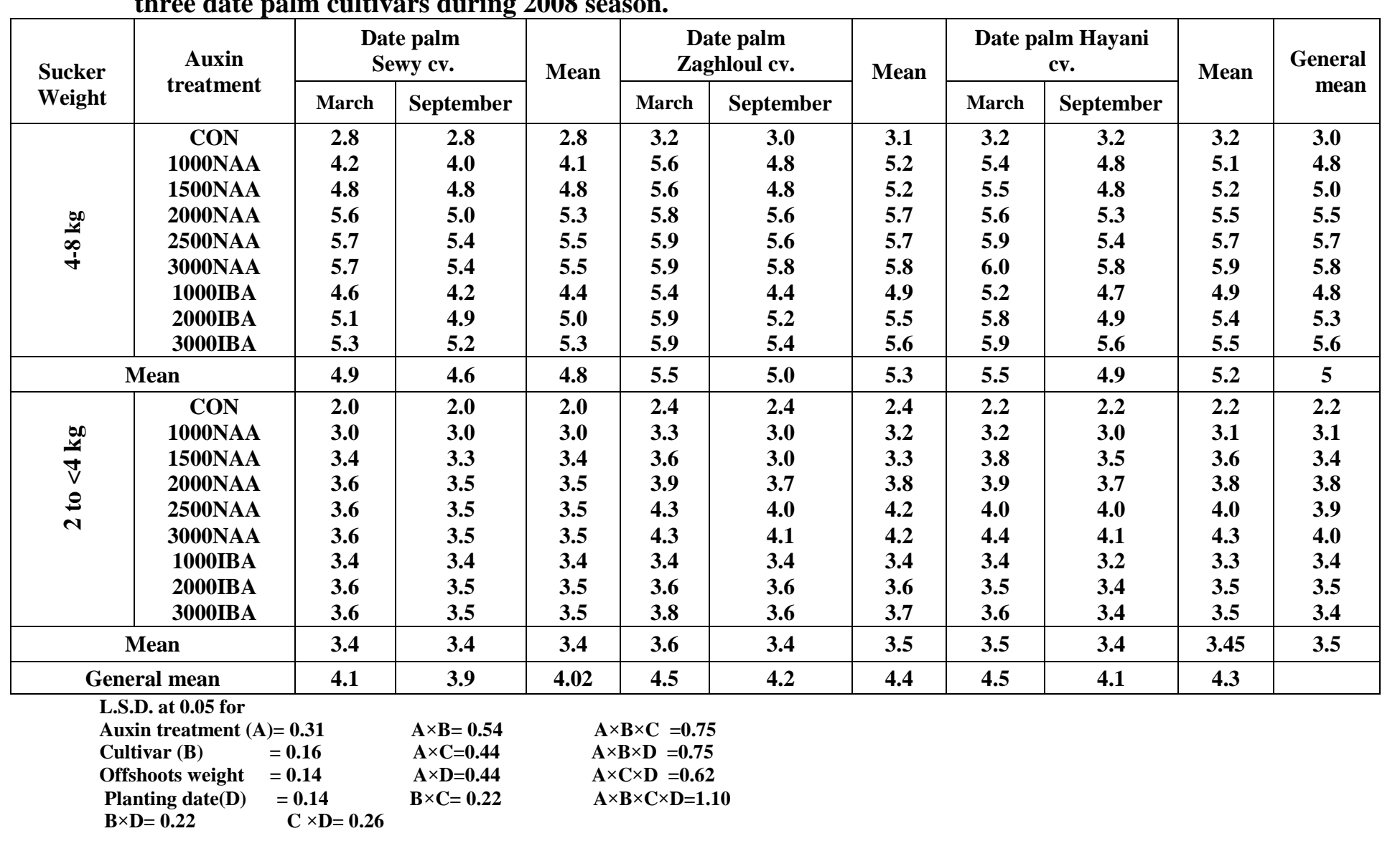


Table (9): Effect of auxin injection, suckers weight and planting date on length of developed leaves (cm) for three cultivars of date palm offshoots during second season 2007.

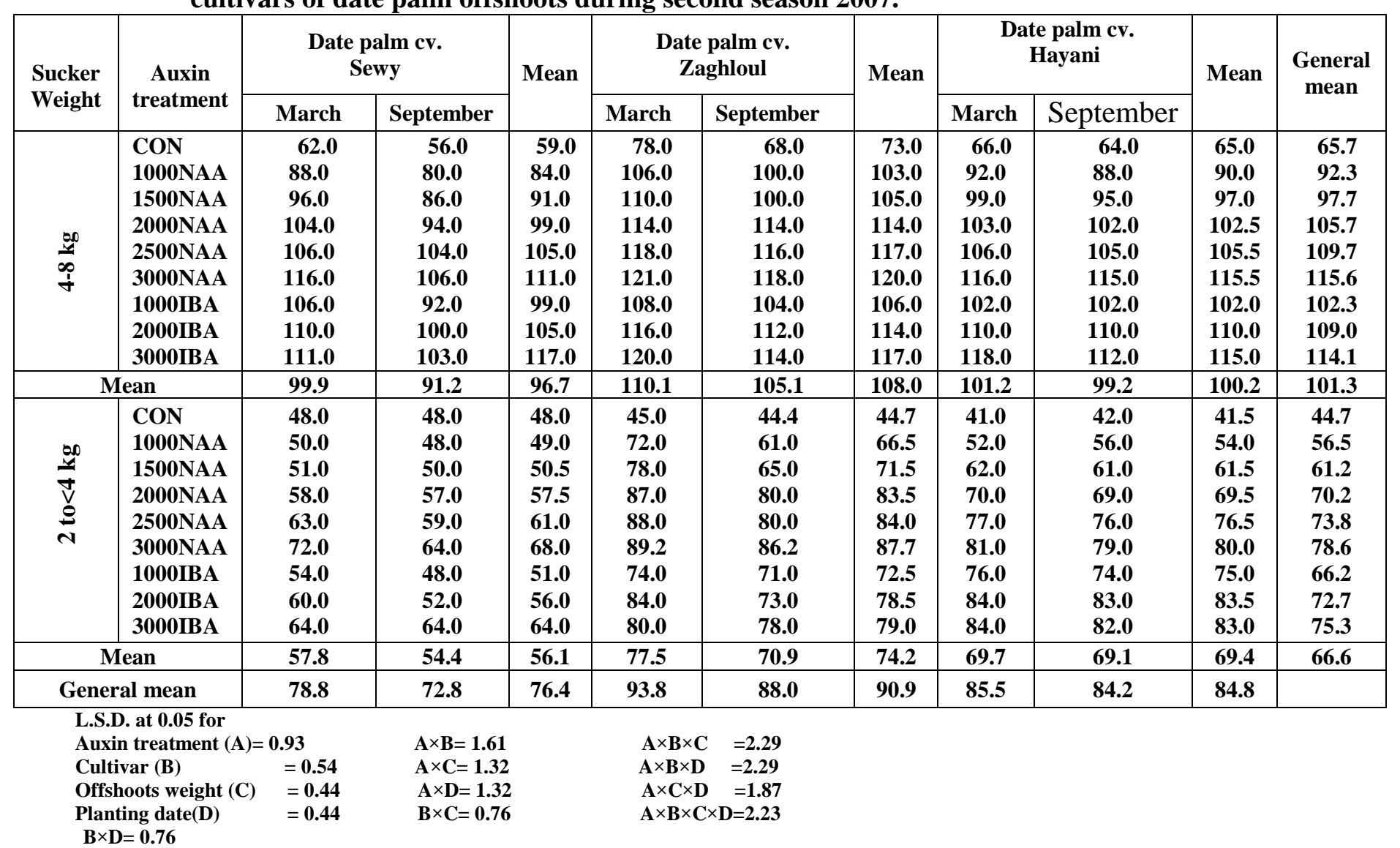


Table (10): Effect of auxin injection, suckers weight and planting date on length of developed leaves (cm) for three cultivars of date palm suckers during second season 2008.

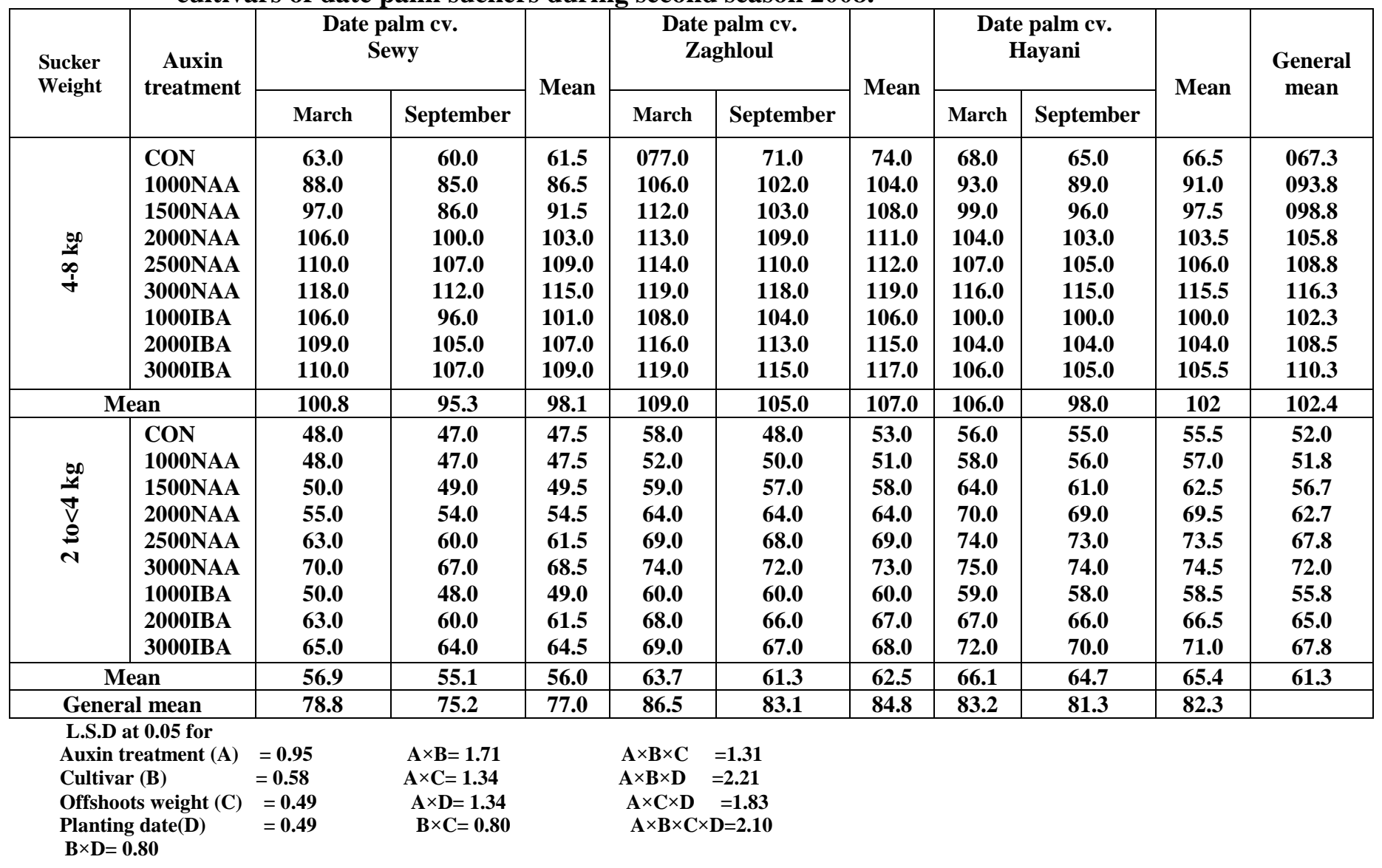


Planting in mid March was better than planting in mid September for all recorded parameters. These results also agreed with Mohamed et al. (1993). They found that offshoot rooting was significantly affected by cultivars.

Using auxin injection in the bases of suckers significantly increased rooting percentage and means of root number, length, diameter, length of leaves and numbers of leaves. Moreover, suckers of Sewy, Zaghloul and Hayany injected with IBA or NAA at $3000 \mathrm{ppm}$ and planted in mid March showed high rooting percentage, length of leaves and numbers of leaves and mean roots number, length and diameter. These results are parallel with the findings of Atalla and Sonbol (1993), Saidi et al. (1993), Lavee et al. (1994), Al-Mana et al. (1996), Rizk and El-Sayed (2003), Qaddory and Amssa (2003 \& 2004), Al-Obeed (2005), Rizk (2006), El-Deeb et al. (2008) and El-Kosary (2009).

\section{Conclusion}

From the aforementioned results, the unused aerial offshoots (suckers) of date palm cvs. Sewy, Hayani, and Zaghloul can be successfully involved in mass propagation by using auxin injection of aerial offshoot bases before planting in the greenhouse using an inverted mist irrigation system. Auxin application can be done by 3000 ppm of either IBA or NAA.

\section{REFERENCES}

Al-Ghamdi A. S. (1988). Rooting of date palm offshoots as affected by offshoots size, cultivar and indole butyric acid injection. Acta Horticulture, 226: 379-388.

Al-Mana F. A., El-Hamady M. A., Bacha M. A. and Abdelrahman A. O. (1996). Improving root development on ground and aerial date palm offshoots. Principes, 40 (4): 179-181.

Al-Obeed R. S. (2005). Rooting of aerial offshoots of four date palm (Phoenix dacytlifera $\mathrm{L}$.) cultivars by air layering method using polyethylene bags. Pakistan J. Bio. Sci. 8(7): 978-981.

Attalla A. M. and Sonbol H. M. (1993). Influence of some growth regulators on root formation of date palm in Saudia. The Third Symposium on Date Palm in K.S.A. (1993).

Bougeudoura N. (1983). Development and distribution of axillary buds in Phoenix dactylifera L. Proc. of The First Symp. on Date Palm. King Faisal Univ., Al-Hassa Sudia Arabia. 23-26 March, Vol. (1): 4045
Dawoud D. H. (2001). Some factors affecting growth and rooting of date palm offshoots. Proceedings of The Second International Conference on Date Palm, Al-Ain, UAE, 25-27 March, 164-175.

EL-Deeb M. D., Sourour M.M. and Marwan M. M. (2008). Vegetative propagation of date palm (Phoenix dactylifera L.) by rooting small offshoots. The Third International Conference On Date Palm, El-Arish Egypt, 25-27 April, pp.9.

El-Hamady A.M., Al-Mana F.A. and Bacha M. A. (1992). Greenhouse rooting of date palm offshoots using an inverted mist system. Annals of Agricultural Science Cairo, 37 (2): 523-530.

El-Hodairi M. H., El-Fagih A. S., Amer A. A. and Subhadrabandhu S. (1992). The effects of indole acetic acid (IAA), indole butyric acid (IBA) and naphthalene acetic acid (NAA) on the growth of Taaghiyaat date palm (Phoenix dactylifera L.). Acta Horticulture, 321: 326-333.

El-Kosary S. (2009). Optimizing date palm aerial offshoots avail through vegetative propagation. J. Sci. Mansoura Univ., 34 (4): 2553-2565.

Gasper T., Kevers C. and Hausman J.F. (1997). In dissociable chief factors in the inductive phase of adventitious rooting. In A. Altman and Y. Waisel (eds), Biology of Root Formation and Development. Plenum Press, New York, p. 55-63.

Gupta O. P. and Godara N. R. (1984). Rooting in aerial offshoots of date palm. Haryana Agric. Univ. J.Res., 14:82-84.

Ismail M. M. and Elegaili F.R. (1993). Effects of IBA growth hormone on root formation of young date palm offshoots. Proceeding of the third symposium on date palm. King Fiasal University, Alhassa, Kingdom of Sudia Arabia.

Lavee S., Avidan N., Pierik R.L.M., Geibel M., Treutter D. and Feucht W. (1994). Chlorogenic acid: an independent morphologesis regulator or a cofactor. Acta Hort., 381: 405-412.

Mohamed S., Mohamed E. and El-Tohami H. (1993). Effect of planting date of the offshoots of the date palms on the rooting percentage, number of roots and number of leaves. Proc. of The Third Symp. on Date Palm. in Saudia Arabia, 17-20 Jan., Vol. (1):209-216. 
Qaddoury A. and Amssa M. (2003). Impact of indole butyric acid on the rooting capacity of young date palm offshoots. Acta Botanica Gallica, 150 (2): 213-222.

Qaddoury A. and Amssa M. (2004). Effect of exogenous indole butyric acid on root formation and peroxibase and indole-3acetic acid oxidase activities and phenolic contents in date palm offshoots. Bot. Bull. Acad. Sin., 45: 127- 131.

Reuveni O. and Adato I. (1974). Endogenous carbohydrates, root promoters and root inhibitors in easy and difficult-to-root date palm (phonix dactylifera L.) offshoots. J. Amer. Soc. Hort. Sci., 99: 361-363.

Rizk S.A.Y. (2006). Some factors affecting on rooting ability of Sewy date palm offshoots in Sewa oasis, Egypt. 2- Effect of offshoot weight and auxin application on rooting \%, and growth of Sewy date palm. Ninufiya J. Agric. Res., 31 (4): 1007-1015.

Rizk S.A.Y. and El-Sayed M. (2003). Physiological studies on the rooting ability of offshoots of some date palm cultivars. The International Conference of Date Palm and Joint Events, Saudia Arabia, King Saudi Univ., Al-Qassem, 16-19 Sept. pp.17. Saidi M., Ellawi M. and Hamdawi E. (1993). Effect of planting date of the offshoots of the date palms on the rooting percentages, number of roots and number of leaves. The Third Symposium on Date Palm in K.S.A., 1993.

Snedecor D.M. and Cochran W.G. (1989). Statistical Methods $6^{\text {th }}$ Ed. The Iowa State Univ. Press, Ames, Iowa, U.S.A.

Sourour M.M. (2001). Rooting ground and aerial offshoots of three date palm cultivars grown in North Sinai using IBA and NAA compounds. J, Adv. Agric. Res., Vol. 6 (4):883-893.

Steel R.G.D. and Torrrie J.H. (1980). Reproduced from Principles and Procedures of Statistics. Printed with the Permission of C. I. Bliss, pp. 448-449.

\title{
استخدام سرطانات نخيل البلح كمادة للإكثار الخضري بواسطة حقتها بمنظمات النمو
}

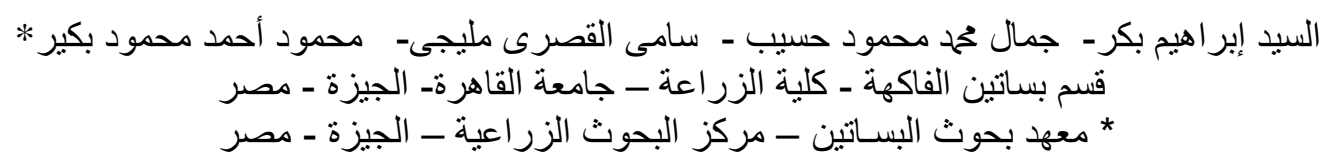

\begin{abstract}
ملخص

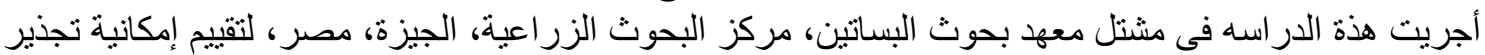

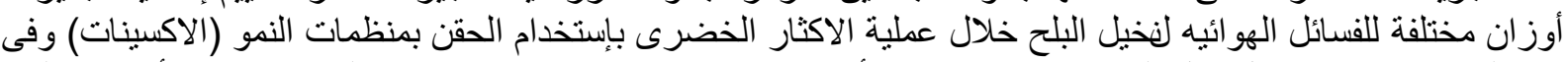

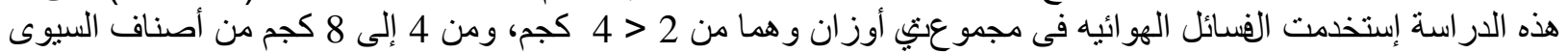

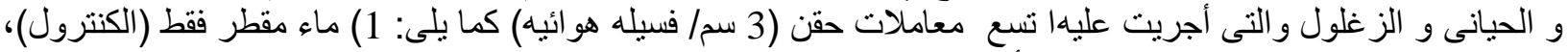

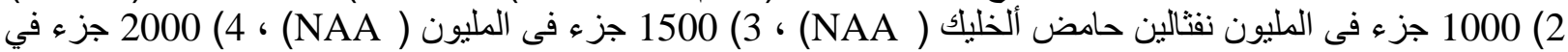

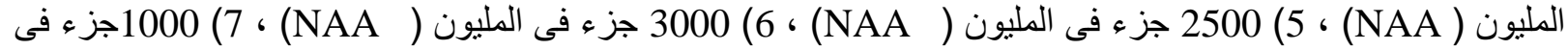

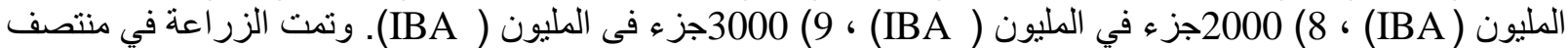

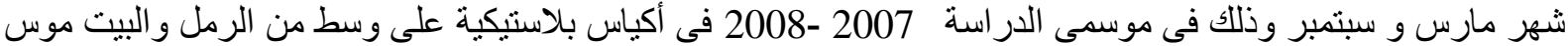

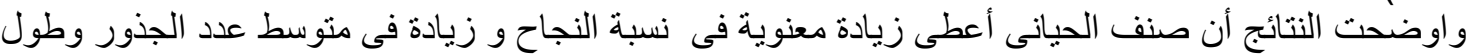
(1:1)

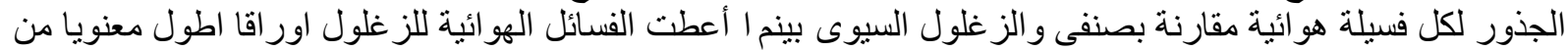

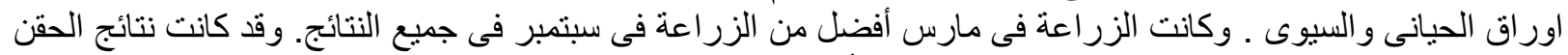

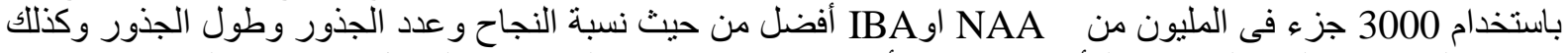

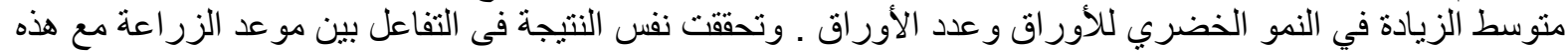

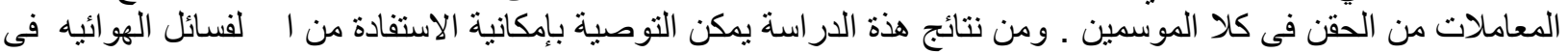

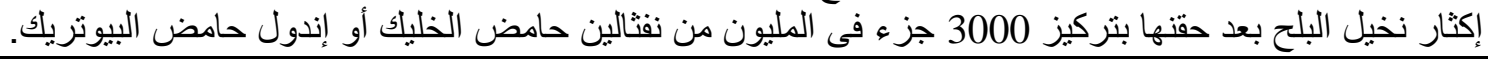
المجلة العلمية لكلية الزراعة - جامعة القاهرة - المجلد (61) العدد الأول ( يناير المئ 2010): 63-78. 